\title{
Natural diet of Macrobrachium brasiliense (Crustacea, Decapoda) in a Cerrado stream
}

\author{
Barbara R. F. da Cruz' (1), Marina C. Cunha' (1), Alessandra A. de P. Bueno² (1) \\ \& Giuliano B. Jacobucci' (1)
}

1. Instituto de Biologia, Universidade Federal de Uberlândia, Rua Ceará, Bloco 2D, 38400-902 Uberlândia, MG, Brazil
(babifer9@gmail.com; marina.cunha@ufu.br; jacobucci@ufu.br)
2. Departamento de Ecologia e Conservação, Universidade Federal de Lavras, Campus Universitário, 37200-000 Lavras, MG, Brazil. (alebueno@ufla.br)

Received 2 September 2020

Accepted 14 January 2021

Published 10 March 2021

DOI 10.1590/1678-4766e2021003

\begin{abstract}
Knowledge about the diet of a given species is essential to provide information on the growth and maintenance of populations in a natural environment. Macrobrachium brasiliense (Heller, 1862) is a species of freshwater prawn widely distributed in Brazil, being frequent in aquatic environments inserted in the Cerrado biome. The aim of this study was to evaluate the natural diet of a population of $M$. brasiliense, comparing the consumed food items according to sex, seasonality and body size of individuals. Monthly collections were carried out between September 2018 and August 2019. The individuals collected had their sex identified and the length of the cephalothorax measured. Stomach content was assessed based on the degree of repletion, the method of points and the frequency of occurrence. There was a high frequency of plant material in the stomach contents and a smaller but significant frequency of aquatic insects. There were no significant differences regarding the diet of males and females and between the dry and rainy seasons. It was observed an increase in total insect consumption with the increase in size of males and females of $M$. brasiliense. A diet preference for Trichoptera was recorded in both sampling periods for males and females. The results obtained confirm an omnivorous diet for the species and suggest that the composition and proportion of items may vary depending on the size of the individuals and the availability of the items in the environment.
\end{abstract}

KEYWORDS. Feeding habits, freshwater prawn, Paleomonidae, abiotic factors.

RESUMO. Dieta natural de Macrobrachium brasiliense (Crustacea, Decapoda) em um córrego de Cerrado.O conhecimento acerca da dieta de uma determinada espécie é essencial para fornecer informações sobre o crescimento e manutenção das populações em ambiente natural. Macrobrachium brasiliense (Heller, 1862) é uma espécie de camarão de água doce com ampla distribuição no Brasil, ocorrendo frequentemente em ambientes aquáticos inseridos no bioma Cerrado. O objetivo deste estudo foi avaliar a dieta natural de uma população de M. brasiliense, comparando os itens alimentares consumidos em função do sexo, sazonalidade e tamanho corporal dos indivíduos. Foram realizadas coletas mensais entre setembro de 2018 a agosto de 2019. Os indivíduos coletados tiveram seu sexo identificado e o comprimento do cefalotórax mensurado. O conteúdo estomacal foi avaliado a partir do grau de repleção, método de pontos e de frequência de ocorrência. Verificou-se elevada frequência de detrito vegetal no conteúdo estomacal e uma frequência menor de insetos aquáticos, porém significativa. Não houve diferenças significativas quanto à dieta de machos e fêmeas e entre as estações seca e chuvosa. Foi observado um aumento do consumo total de insetos com aumento de tamanho de machos e fêmeas de M. brasiliense. Uma preferência de dieta por Trichoptera foi registrada em ambos os períodos de amostragem para machos e fêmeas.Os resultados obtidos confirmam uma dieta onívora para a espécie e sugerem que a composição e a proporção de itens podem variar em função do tamanho dos indivíduos e da disponibilidade dos itens no ambiente.

PALAVRAS-CHAVE. Hábitos alimentares, camarão de água doce, Palaemonidae, fatores abióticos.

In continental aquatic ecosystems, benthic communities are constituted by a high diversity of invertebrates, including larvae and / or adults of insects, molluscs, annelids and crustaceans (ESTEVEs, 2011). Among crustaceans, prawns can be dominant in terms of biomass in streams and rivers in tropical regions, particularly in freshwater environments that have a connection with the marine environment (BAUER, 2004). Although the majority of prawn species are amphidromic, that is, they depend on the estuarine or oceanic environment to complete their life cycle, other species, called hololimnetics, develop exclusively in freshwater environments (CHACE \& HOBBS, 1969; BENSTEAD et al., 2000; BAUER, 2004).
Freshwater prawns play an important trophic role in the aquatic ecosystems in which they occur, because in addition to being important consumers, they serve as a food resource for reptiles (BoRTEIRO et al., 2009), fishes (HALUCH et al., 2009) and humans (ODInetz-Collart \& Moreira, 1993; BondBucKuP et al., 2009). These crustaceans are considered key species in the functioning of aquatic ecosystems, as they can influence the structuring of benthic communities, as well as in ecological processes such as leaf debris degradation (MENGE et al., 1994). However, its effect depends on the feeding habit and the abundance of species present in a given location.

Although most prawns are omnivorous, there is high intra and interspecific variability in the composition and 
relative frequency of the different items present in the diet of these decapods (AlberToni et al., 2003; Melo \& NAKAGAKI, 2013; Sethi et al., 2013). Such variation is due to the type of environment in which these animals occur and the availability of food resources (LAVAJOo et al., 2019).

Currently, about 50 species of freshwater prawns are registered in Brazilian waters, distributed in four families (Atyidae, Euryrhynchidae, Palaemonidae and Sergestidae) (Melo, 2003; Pileggi \& Mantelatto, 2012; Costa \& Simões, 2016; Magalhães et al., 2016a,b; Mantelatto et al., 2016a,b).The Palaemonidae family has the largest number of representatives in continental waters in Brazil and in the world (Holthuis, 1952; ANGer, 2013).

The genus Macrobrachium Bate, 1868 is the most diverse in this family and occurs in Asia, Africa, Australia and the Americas, being currently represented by about 250 species (MAGALHÃES et al., 2016a; SAENGPHAN et al., 2018; Rossi et al., 2020). In South America, the genus has a wide distribution and is found in many river basins including the Orinoco, Amazon, Paraguay, Paraná and São Francisco River basins. According to ANGER (2013), it is likely that many species have not yet been identified, making the real number of neotropical species of Macrobrachium much greater. In Brazil, the genus is represented until now by 19 native species (De Grave \& Fransen, 2011; Pileggi \& Mantelatto, 2012; Dos SANTOS et al., 2013; Rossi et al., 2020).

Macrobrachium brasiliense (Heller, 1862) is a species with wide distribution, occurring exclusively in freshwater environments of South America, in Venezuela, Colombia, Guyana, Suriname, French Guiana, Ecuador, Peru and Brazil (Holthuis, 1980; Melo, 2003). In Brazil, the species is recorded in the states of Acre, Amapá, Pará, Amazonas, Maranhão, Bahia, Mato Grosso, Mato Grosso do Sul, Goiás, Bahia, Minas Gerais, São Paulo and Paraná (GARCíA-DÁvILA \& Magalhães, 2003; Pileggi et al., 2013).

Most of the studies related to $M$. brasiliense refer to species surveys (Magalhães, 2000; PilegGi et al., 2013; SANTOS et al., 2018) and works on population and reproductive biology (García-Dávila et al., 2000; Mantelatto \& Barbosa, 2005; Pereira \& Chacur, 2009; Nogueira et al., 2019; OLIVEIRA et al., 2019). Investigations regarding the diet of this species are very rare (Melo \& NAKAGAKI, 2013).

In central Brazil, the occurrence of $M$. brasiliense is mainly associated with aquatic ecosystems inserted in the Cerrado. This biome is currently one of the most impacted in Brazil, with aquatic environments altered by erosive processes resulting from deforestation of riparian vegetation and contamination by different types of pollutants (KLINK \& MACHADO, 2005). The impact of pasture areas is particularly strong in streams because it favors the increase of organic and inorganic particulate material, silting up and homogenizing of habitats which can reduce diversity of shelter and food resources for fishes and macrofauna (DIAS \& TEJERINAGARRO, 2010; Mesa et al., 2013). Dietary studies in altered aquatic environments can offer relevant information about the impacts of these anthropic changes on the feeding habits of organisms that occur in these environments.
In this context, the objective of this study was to evaluate the diet of a population of $M$. brasiliense occurring in a watercourse altered by the removal of riparian vegetation and the presence of adjacent pasture areas, located in the west of Minas Gerais state, a region of Cerrado domain. We tested the following hypotheses: the diet has a lower variety of food items in relation to the diet of $M$. brasiliense individuals in more preserved areas; differences of diet are expected between seasons, because environmental conditions and food availability can change; differences of diet are not expected between males and females, because they have similar food requirements; differences of diet with size are expected, because prawns can have different requirements and/or capacities to feed different items during their life cycle.

\section{MATERIAL AND METHODS}

Study area. The study was carried out from September 2018 to August 2019 in the city of Uberlândia, on the Uberlândia - Campo Florido Road, in a tributary of the Douradinho stream (Tijuco river basin) (Fig. 1), about 500 meters from the entrance of Fazenda Água Limpa (19 $\left.08^{\prime} 24^{\prime \prime} \mathrm{S}, 48^{\circ} 22^{\prime} 44^{\prime \prime} \mathrm{W}\right)$, belonging to the Universidade Federal de Uberlândia. The stream section sampled had degraded riparian vegetation, with a predominance of grasses on its banks and pasture land use in its surroundings. The climate of the region is of the tropical type AW of Köppen (KöPPEN, 1948), hot and humid, with dry season in winter (April to September) and rainy in summer (October to March).

Sampling and processing. Monthly samplings of Macrobrachium brasiliense were carried out on the banks of the stream, in a $50 \mathrm{~m}$ long stretch, using a sieve with 3 $\mathrm{mm}$ mesh size. The sieve was dipped under the submerged vegetation and leaf litter deposited at the bottom and raised with a rapid and upward movement. The movements with the sieve were repeated for a period of 30 minutes and all prawns found were collected. This period enables sampling between 20 to 30 individuals every month.

Before each prawn collection, the physical and chemical parameters of the water were measured: surface water temperature, $\mathrm{pH}$, conductivity, turbidity, dissolved oxygen, and total concentration of dissolved solids (TDS), using a multiparameter (Horiba). The water speed was measured at the beginning, at the end and at two intermediate points of the collection stretch using a digital meter. Water parameters were evaluated to characterize stream condition in dry and rainy seasons. All samplings were performed in the morning, between 9 and 11 a.m.

The captured individuals were immediately placed in a thermal box with ice to preserve the stomach contents of the individuals and transported to the laboratory. The specimens were stored separately in labeled bottles containing $70 \%$ ethanol until stomach analysis. The cephalothorax length (CL) - distance between the posterior margin of the right orbit to the midpoint of the posterior margin of the carapace - was measured using a caliper with $0.05 \mathrm{~mm}$ precision. 


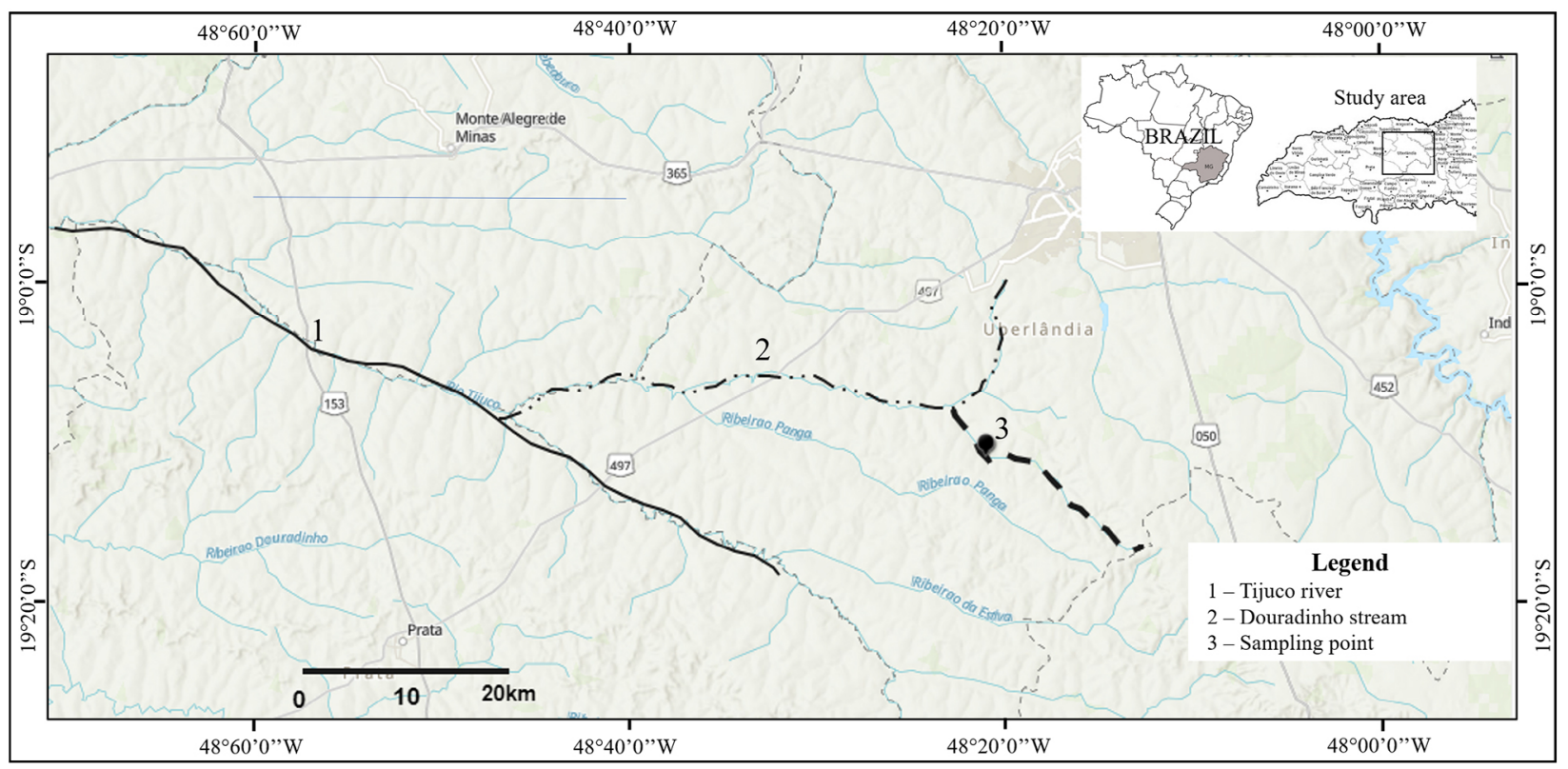

Fig. 1. Map of the study area in the western region of Minas Gerais state, Brazil and sampling stretch (1) of Macrobrachium brasiliense (Heller, 1862).

Males and females were identified according to the presence or absence of the appendix masculina in the endopod of the second pair of pleopods, respectively, from a stereomicroscope, following criteria of MANTELATTO \& BARBOSA (2005). There was a minimal size that allowed observing the male appendage and sex determination. Thus, the size of the lowest male individual found, determined the minimum size (CL) to verify sex, according to BAUER (1989). All specimens smaller than the smallest male were considered undetermined sex juveniles. These juveniles were not evaluated for diet.

The stomach contents of all males and females collected were analyzed, removing the stomachs with the aid of scissors and forceps from a cut on the back of the cephalothorax. The material contained in the stomachs was removed with jets of $70 \%$ ethanol using a Pasteur pipette and placed in a Petri dish with graph paper at the bottom (BUENO \& BOND-BUCKUP, 2004).

Stomach fullness based on the relative amount of food in the stomachs was estimated. Stomach content that was not identified, due to its high level of digestion, was considered as unidentified digested material. The food items found in each individual were identified using a key for benthic fauna (Mugnai et al., 2010).

To assess the availability of benthic organisms in the sampling site, a collection was carried out in the rainy season, in February 2019 and another in the dry season, in July 2019. Benthic organisms were collected by dragging a $\mathrm{D}$ net on the stream bed. on both stream banks. The collected material was packed in plastic bags, fixed in $10 \%$ formaldehyde and identified.

In the laboratory, the material was washed in a $0.5 \mathrm{~mm}$ sieve. Retained benthic organisms were identified at the order level, with the aid of a stereomicroscope and an identification key (Mugnar et al., 2010) and subsequently quantified.
Data analysis. The data were evaluated for normality and homoscedasticity and when necessary appropriately transformed to meet the assumptions of parametric tests. When data do not meet these assumptions, non-parametric tests were used (ZAR, 2010). The water physical and chemical parameters were compared between the dry (September 2018, April to August 2019) and rainy (October 2018 to March 2019) seasons using $t$ test for parametric data and Wilcoxon test for non-parametric data (ZAR, 2010).

The degree of fulness was determined visually, according to the amount of food present in the stomachs, following a six-class scale (WiLliams, 1981). To quantify the food items ingested, they were grouped by frequency of occurrence (FO: WiLliams, 1981, WeAR \& HADDON, 1987, HAEFNER JÚNIOR, 1990) using the equation FO $=\mathrm{si} / \mathrm{N}$ .100 (where: $\mathrm{si}=$ number of stomachs containing item $\mathrm{i}$ and $\mathrm{N}=$ number of individuals sampled) and the point method (PM: BRANCO \&VERANI, 1997) using a five-degree scale: degree $1=<5 \%$ ( 2.5 points), degree $2=5$ to $35 \%$ ( 25 points), degree $3=35$ to $65 \%$ (50 points), degree $4=65$ to $95 \%$ ( 75 ) points and degree $5=>95 \%$ (100 points). The number of points each item received was attributed according to the degree of fullness value by multiplying the number of points by an abundance-class value: class $1=0.00$, class $2=0.02$, class $3=0.25$, class $4=0.50$, class $5=0.75$ and class $6=1.00$. The total percentage of points for an item was expressed by the formula ${ }^{n} \sum_{j=1}\left(a_{i j} / A\right) .100$ (where: $a i j=$ number of points of the prey itemi found in the stomachs of the individuals examined; $\mathrm{A}=$ total number of points for all items; $\mathrm{n}=$ total number of stomachs examined) (WiLLIAMs, 1981).

To analyze the relationship between stomach content and the size of individuals, a linear regression was performed using the Microsoft Excel computer program (version 2019), obeying the premises of homogeneity and homoscedasticity (ZAR, 2010). To compare the degree of fullness between 
males and females, $t$ test was used. The Chi-square test was used to compare the frequency of occurrence (FO) and the absolute frequency of points (MP) of food items consumed by males and females between the dry and rainy seasons. In these last tests, the RStudio program was used, following the procedures described by ZAR (2010). For all tests, a significance level of $\mathrm{p}<0.05$ was considered.

To identify the possibility of food preference for M. brasiliense, the Foraging Rate (FR) was calculated, in which values greater than 1 indicate food preference and the Ivlev Electivity Index (Ei), which vary between -1 and +1 and values found between 0 and +1 indicate preference. These indexes consider the proportion of the items found in the stomachs analyzed and their availability in the natural environment, according to the premises of KREBS (1999) and the methodology proposed by BUENO \& BOND-BUCKUP (2004). Both FR and Ei were calculated by season (dry and rainy).

\section{RESULTS}

Only the surface water temperature $(\mathrm{t}=3.17 ; \mathrm{df}=$ $6.00 ; \mathrm{p}=0.02)$ and turbidity $(\mathrm{w}=31 ; \mathrm{p}=0.04)$ parameters showed significant variation between seasons, with higher temperature and turbidity in the rainy season (Fig. 2).

A total of 219 individuals of $M$. brasiliense were analyzed, 68 males, with CL ranging from $3.1 \mathrm{~mm}$ to $8.0 \mathrm{~mm}$ and 151 females, with CL ranging from $3.1 \mathrm{~mm}$ and $9.3 \mathrm{~mm}$. In the dry season, 83 individuals were recorded, of which 26 had empty stomachs (69.23\% females, $30.77 \%$ males) and 57 had stomach contents $(70.18 \%$ females; $29.82 \%$ males). There were no significant differences between males (mean +sd: $3.38+1.77)$ and females (mean + sd: $2.91+$ $1.68)$ in relation to the degree of stomach fullness $(t=1.85$; $\mathrm{df}=217 ; \mathrm{p}=0.065)$. In the rainy season, 136 individuals were recorded, of which 35 had empty stomachs and 101 had stomach contents (Tab. I). There were no significant differences in the degree of stomach fullness between the dry (mean +sd: $2.87+1.56)$ and rainy (mean + sd: $3.46+$ $1.83)$ seasons $(\mathrm{t}=2.48 ; \mathrm{df}=217 ; \mathrm{p}=0.09)$.

Ten items were identified composing the diet of M. brasiliense, including: unidentified digested material, plant detritus, unidentified insects, Trichoptera, Odonata, Coleoptera, Diptera, Ephemeroptera, Plecoptera and sand. The item plant detritus was composed by fragments of leaves, seeds, sticks and roots. The item unidentified insects included wings, antennae, legs and other structures that could not be identified at the order level.

The analysis of the absolute frequency of points and the frequency of occurrence indicated that the item plant detritus was the item most found in the stomachs. However, when compared to the total material of animal origin this item is no longer predominant (Tabs II, III).

The frequency of food items in the stomachs did not vary between males and females in the dry season (FO: $\chi^{2}=$ $\left.62.5, \mathrm{df}=56, \mathrm{p}=0.26 ; \mathrm{MP}: \chi^{2}=42, \mathrm{df}=36, \mathrm{p}=0.22\right)$ and the same was observed in the rainy season (FO: $\chi^{2}=70, \mathrm{df}=$ $63, \mathrm{p}=0.25 ; \mathrm{MP}: \chi^{2}=90, \mathrm{df}=81, \mathrm{p}=0.23$ ), although only females have ingested Ephemeroptera in the dry period and Plecoptera in the rainy period (Tab. III).

Considering that there were no differences between the proportions of items ingested in the two seasons, individuals were grouped and the influence of prawn size $(\mathrm{CL})$ on food intake according to sex was analyzed. The linear regression lines showed no effect of the size on the consumption of plant detritus (Males: $F=1.950 ; p=0.172$ / Females: $F=2.086$; $\mathrm{p}=0.152$ ), Coleoptera (Females: $\mathrm{F}=2.845 ; \mathrm{p}=0.112$ ) and Odonata (Females: $F=3.013 . p=0.104)$. Linear regressions analyses were not performed for the items Coleoptera and Odonata in males, as the number of animals that contained these items in their stomachs was very low $(\mathrm{n}<6)$. Differences in the intake of Plecoptera and Ephemeroptera by males and females according to size were also not compared, due to the low occurrence of these insects in the stomachs $(n<4)$.

An increase was found in the intake of items as a function of size for the total of insect items (Males: $\mathrm{F}=14.177$; $\mathrm{p}=0.0006 ; \mathrm{r}^{2}=0.30 /$ Females: $\mathrm{F}=14.322 ; \mathrm{p}=0.0003 ; \mathrm{r}^{2}=$ 0.021 ) and for Trichoptera (Males: $F=5.116 ; p=0.0379 ; r^{2}=$ 0.24 / Females: $\mathrm{F}=5.628 ; \mathrm{p}=0.0218 ; \mathrm{r}^{2}=0.11$ ) and Diptera (Females: $F=8.026 ; p=0.0220 ; r^{2}=0.50$ ). It was not possible to perform linear regression on data referring to the presence of Diptera in the male stomachs because $n<5$ (Fig. 3).

When analyzing the food availability of the environment in each season, it was observed that the most abundant order, both in the dry and rainy seasons, was Diptera ( $48 \%$ dry; $38 \%$ rainy), followed by Trichoptera (14\% dry; $8 \%$ rainy) and Coleoptera (12\% dry; $23 \%$ rainy) (Tab. IV).

Regarding food preferences, both males and females, regardless of the season, preferred Trichoptera (Dry season

Tab. I. Absolute and relative frequency (\%) of females and males of Macrobrachium brasiliense (Heller, 1862) with empty stomach and with content, sampled in a stream, Uberlândia, Minas Gerais state, Brazil in the dry and rainy seasons.

\begin{tabular}{|c|c|c|c|c|c|c|}
\hline \multirow{2}{*}{ Sex } & \multirow{2}{*}{ Season } & \multicolumn{2}{|c|}{ Empty stomach } & \multicolumn{2}{|c|}{ Stomach with contents } & \multirow{2}{*}{ Total } \\
\hline & & $\mathrm{n}$ & $\%$ & $\mathrm{~N}$ & $\%$ & \\
\hline Females & dry & 18 & 69.23 & 40 & 70.18 & 58 \\
\hline Males & dry & 8 & 30.77 & 17 & 29.82 & 25 \\
\hline Total & & 26 & 100 & 57 & 100 & 83 \\
\hline Females & rainy & 19 & 54.29 & 74 & 73.27 & 93 \\
\hline Males & rainy & 16 & 45.71 & 27 & 26.73 & 43 \\
\hline Total & & 35 & 100 & 101 & 100 & 136 \\
\hline
\end{tabular}



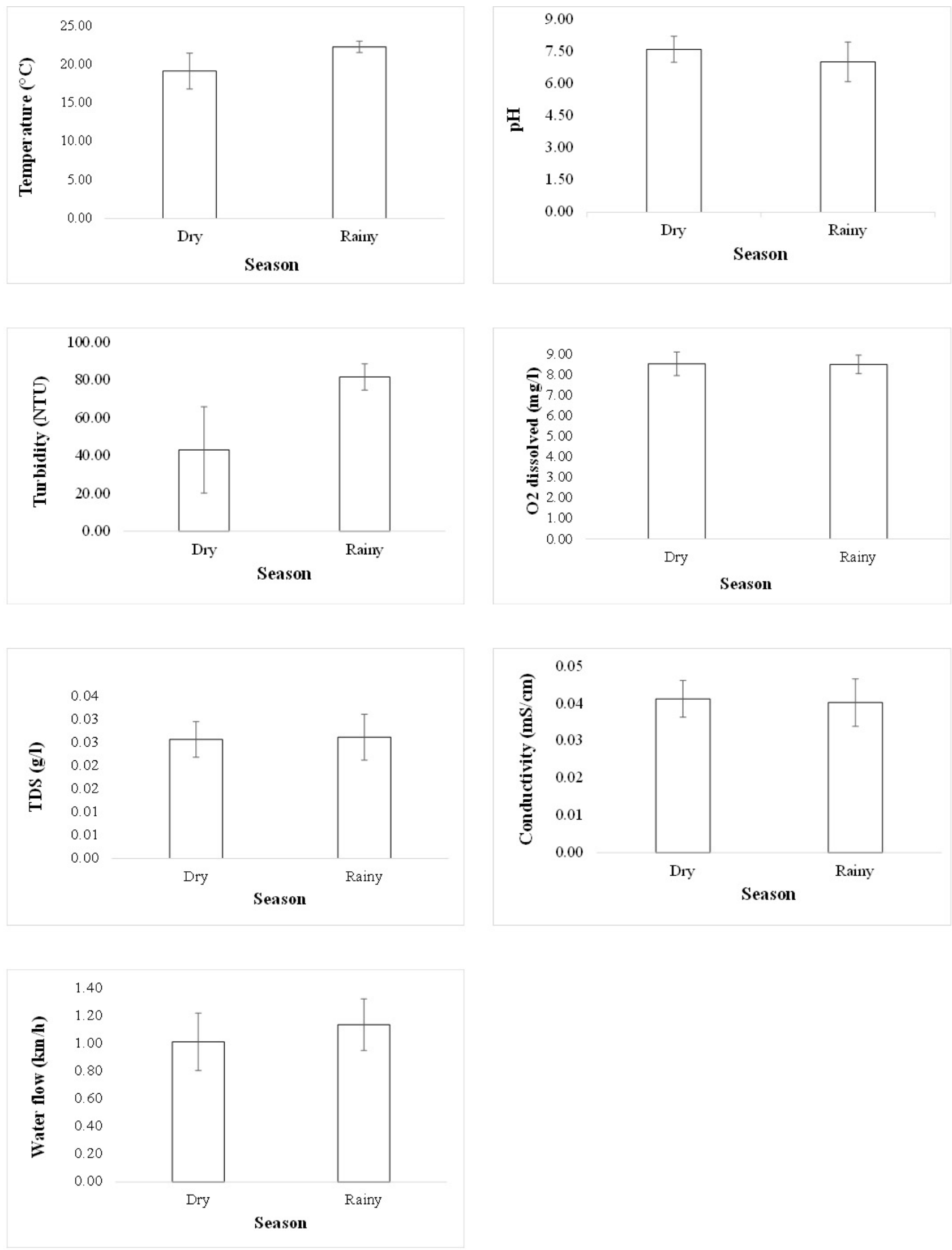

Fig. 2. Physical and chemical water parameters $($ mean $+\mathrm{sd})$ sampled in the stream, Uberlândia, Minas Gerais state, Brazil in the dry and rainy seasons. 
Tab. II. Absolute frequency of points (MP) and relative frequency (FR\%) of the items found in the stomachs of Macrobrachium brasiliense (Heller, 1862) sampled in the stream, Uberlândia, Minas Gerais state, Brazil in the dry and rainy seasons.

\begin{tabular}{lcccccccc}
\hline & \multicolumn{3}{c}{ Dry } & \multicolumn{3}{c}{ Rainy } \\
\cline { 2 - 9 } Items & $\begin{array}{c}\text { Males } \\
\text { (MP) }\end{array}$ & $\begin{array}{c}\text { FR } \\
(\%)\end{array}$ & $\begin{array}{c}\text { Females } \\
(\mathrm{MP})\end{array}$ & $\begin{array}{c}\text { FR } \\
(\%)\end{array}$ & $\begin{array}{c}\text { Males } \\
(\mathrm{MP})\end{array}$ & $\begin{array}{c}\text { FR } \\
(\%)\end{array}$ & $\begin{array}{c}\text { Females } \\
(\mathrm{MP})\end{array}$ & $\begin{array}{c}\text { FR } \\
(\%)\end{array}$ \\
\hline Digested material & 241.00 & 32.47 & 750.00 & 38.85 & 562.50 & 32.19 & 1555.00 & 30.49 \\
Plant detritus & 194.25 & 26.17 & 378.00 & 19.58 & 441.00 & 25.24 & 1323.25 & 25.95 \\
Unidentified insect & 75.50 & 10.17 & 176.00 & 9.12 & 268.75 & 15.38 & 600.50 & 11.78 \\
Trichoptera & 106.55 & 14.35 & 293.50 & 15.20 & 281.25 & 16.10 & 825.50 & 16.19 \\
Odonata & 31.25 & 4.21 & 156.25 & 8.09 & 25.00 & 1.43 & 162.50 & 3.19 \\
Coleoptera & 18.75 & 2.53 & 126.00 & 6.53 & 50.00 & 2.86 & 218.75 & 4.29 \\
Diptera & 68.75 & 9.26 & 31.80 & 1.65 & 18.75 & 1.07 & 100.00 & 1.96 \\
Ephemeroptera & 0.00 & 0.00 & 18.75 & 0.97 & 31.25 & 1.79 & 62.50 & 1.23 \\
Plecoptera & 0.00 & 0.00 & 0.00 & 0.00 & 0.00 & 0.00 & 19.25 \\
Sand & 6.25 & 0.84 & 0.00 & 0.00 & 68.75 & 3.93 & 232.25 \\
\hline \multicolumn{1}{c}{ Total } & 742.30 & & 1930.30 & & 1747.25 & & 5.38 \\
\hline
\end{tabular}

Tab. III. Frequency of occurrence (FO) of the items found in the stomachs of males and females of Macrobrachium brasiliense (Heller, 1862) sampled in the stream, Uberlândia, Minas Gerais state, Brazil in the dry and rainy seasons.

\begin{tabular}{|c|c|c|c|c|c|c|c|c|}
\hline \multirow{2}{*}{ Items } & \multicolumn{4}{|c|}{ Dry } & \multicolumn{4}{|c|}{ Rainy } \\
\hline & Males & $\%$ & Females & $\%$ & Males & $\%$ & Females & $\%$ \\
\hline Digested material & 14 & 28 & 35 & 34.31 & 25 & 32.05 & 67 & 28.39 \\
\hline Plantdetritus & 13 & 26 & 24 & 23.53 & 21 & 26.92 & 59 & 25.00 \\
\hline Unidentified insects & 5 & 10 & 10 & 9.80 & 12 & 15.38 & 28 & 11.86 \\
\hline Trichoptera & 8 & 16 & 14 & 13.73 & 11 & 14.10 & 37 & 15.68 \\
\hline Odonata & 3 & 6 & 7 & 6.86 & 1 & 1.28 & 9 & 3.81 \\
\hline Coleoptera & 2 & 4 & 7 & 6.86 & 2 & 2.56 & 10 & 4.24 \\
\hline Diptera & 4 & 8 & 4 & 3.92 & 1 & 1.28 & 5 & 2.12 \\
\hline Ephemeroptera & 0 & 0 & 1 & 0.98 & 2 & 2.56 & 3 & 1.27 \\
\hline Plecoptera & 0 & 0 & 0 & 0.00 & 0 & 0.00 & 2 & 0.85 \\
\hline Sand & 1 & 2 & 0 & 0.00 & 3 & 3.85 & 16 & 6.78 \\
\hline Total & 50 & 100 & 102 & 100 & 78 & 100 & 236 & 100 \\
\hline
\end{tabular}

Tab. IV. Proportion of benthic macroinvertebrates sampled in the environment in the stream, Uberlândia, Minas Gerais state, Brazil in the dry and rainy seasons.

\begin{tabular}{|c|c|c|}
\hline \multirow{2}{*}{ Order } & \multicolumn{2}{|c|}{ Season } \\
\hline & Dry & Rainy \\
\hline Coleoptera & $11.70 \%$ & $22.92 \%$ \\
\hline Collembola & $2.48 \%$ & $0.00 \%$ \\
\hline Diptera & $48.23 \%$ & $38.19 \%$ \\
\hline Ephemeroptera & $8.16 \%$ & $6.94 \%$ \\
\hline Hemiptera & $3.90 \%$ & $0.00 \%$ \\
\hline Heteroptera & $1.77 \%$ & $9.03 \%$ \\
\hline Megaloptera & $1.77 \%$ & $0.00 \%$ \\
\hline Odonata & $7.80 \%$ & $11.11 \%$ \\
\hline Plecoptera & $0.00 \%$ & $3.47 \%$ \\
\hline Trichoptera & $14.18 \%$ & $8.33 \%$ \\
\hline
\end{tabular}

- Males: FR $=1.60, \mathrm{Ei}=0.23$; Females: FR $=1.94, \mathrm{Ei}=$ 0.32 / Rainy season - Males: $\mathrm{FR}=1.34, \mathrm{Ei}=0.15$; Females $\mathrm{FR}=1.06, \mathrm{Ei}=0.03)$. In the dry season, the male foraging rate data for Odonata were very marginal $(*)$ and almost indicated a preference for that insect order (Tab. V). 


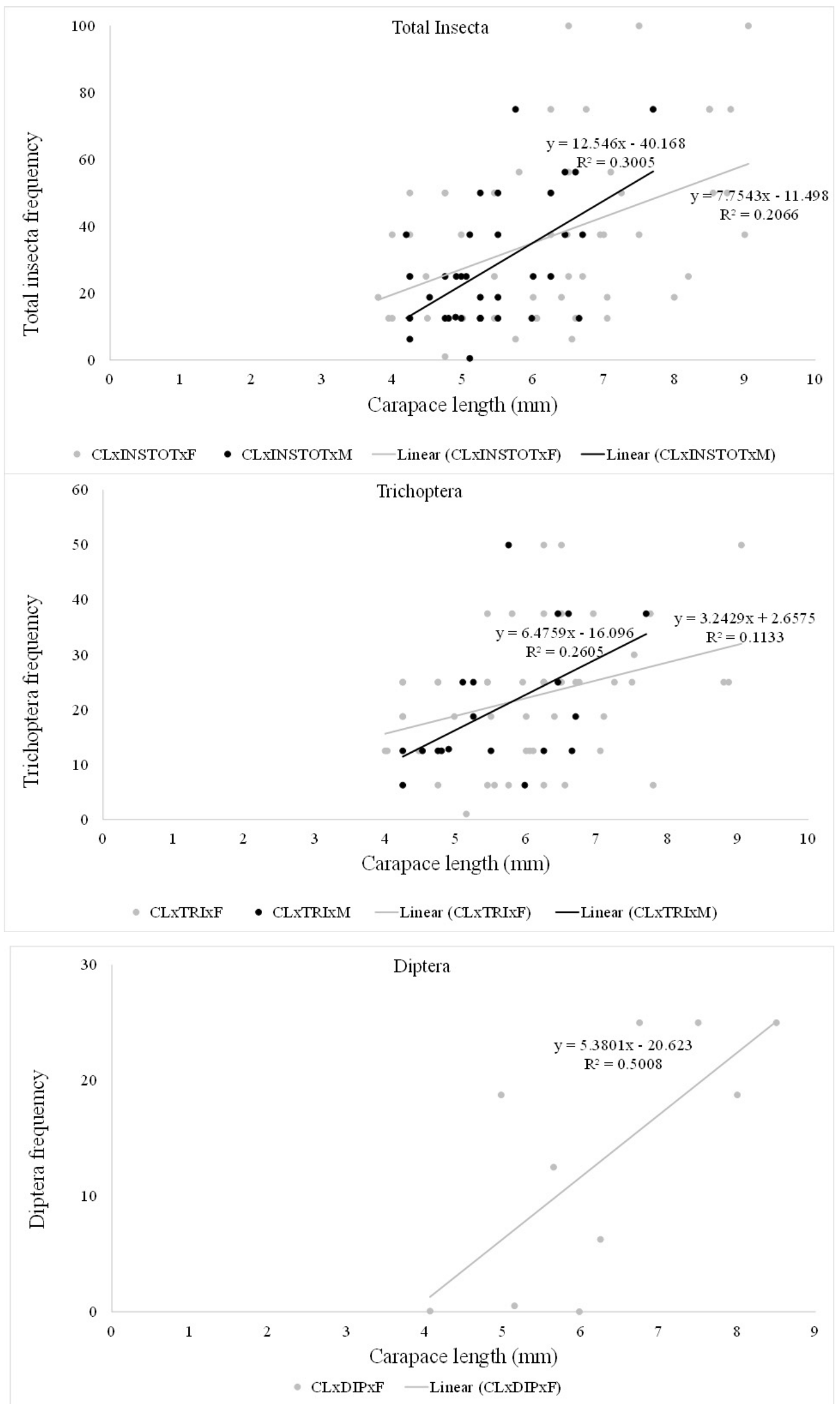

Fig. 3. Linear regression between cephalothorax length (CL) and frequency of total insects; Trichoptera (for prawn males and females) and Diptera (for prawn females) in the diet of Macrobrachium brasiliense (Heller, 1862) (method of points) (CL, cephalothorax lenght; INSTOT, total insects; F, females - grey dots; M, males - black dots). 
Tab. V. Occurrence frequency (OF), Foraging rate (FR) and electivity index (Ei) of Macrobrachium brasiliense (Heller, 1862) in dry and rainy seasons.

\begin{tabular}{|c|c|c|c|c|c|c|c|}
\hline \multicolumn{8}{|c|}{ Rainyseason } \\
\hline \multirow{2}{*}{ Order } & \multirow{2}{*}{$\begin{array}{c}\text { Environment } \\
\text { OF (\%) }\end{array}$} & \multicolumn{3}{|c|}{ Males } & \multicolumn{3}{|c|}{ Females } \\
\hline & & OF (diet \%) & FR & $\mathrm{Ei}$ & OF (diet \%) & FR & $\mathrm{Ei}$ \\
\hline Trichoptera & 8.33 & 13.30 & 1.60 & 0.23 & 16.19 & 1.94 & 0.32 \\
\hline Odonata & 11.11 & 2.22 & 0.20 & -0.67 & 2.86 & 0.26 & -0.59 \\
\hline Coleoptera & 22.92 & 4.44 & 0.19 & -0.68 & 3.81 & 0.17 & -0.71 \\
\hline Diptera & 38.19 & 2.22 & 0.06 & -0.89 & 2.86 & 0.07 & -0.86 \\
\hline Ephemeroptera & 6.94 & 4.44 & 0.64 & -0.22 & 0.95 & 0.14 & -0.76 \\
\hline Plecoptera & 3.47 & 0.00 & 0.00 & -1.00 & 0.95 & 0.27 & -0.57 \\
\hline \multicolumn{8}{|c|}{ Dryseason } \\
\hline \multirow{2}{*}{ Order } & Environment & \multicolumn{3}{|c|}{ Males } & \multicolumn{3}{|c|}{ Females } \\
\hline & OF $(\%)$ & OF (diet \%) & FR & $\mathrm{Ei}$ & OF (diet \%) & FR & $\mathrm{Ei}$ \\
\hline Trichoptera & 14.18 & 19.00 & 1.34 & 0.15 & 15.00 & 1.06 & 0.03 \\
\hline Odonata & 7.80 & 7.70 & $0.99 *$ & -0.01 & 5.00 & 0.64 & -0.22 \\
\hline Coleoptera & 11.70 & 3.84 & 0.33 & -0.51 & 7.50 & 0.64 & -0.22 \\
\hline Diptera & 48.23 & 3.84 & 0.08 & -0.85 & 0.00 & 0.00 & -1.00 \\
\hline
\end{tabular}

\section{DISCUSSION}

In the present study, differences in surface water temperature and turbidity were found when the two analyzed seasons were compared. The increase in temperature and water turbidity in the rainy season are usually recorded in lotic environments. This happens because of the rainy season (from March to October) corresponds to the period of higher air temperatures and precipitation, resulting in increase of surface water temperature and input of sediment from the margins (GuIMarÃes-Souto et al., 2011). However, the surface water temperature and turbidity variability were not enough to result in differences in food availability of the main animal itens and probably also of the plant material to cause diet changes between dry and rainy seasons.

The proportion of empty stomachs recorded in studies of natural diet of other species of Macrobrachium is considerably variable ranging from $2.87 \%$ to $99 \%$ of the stomachs analyzed (ALBERTONI et al., 2003; SETHI et al., 2013; Lima et al., 2014; Lavajoo et al., 2019). The values obtained in the present study were remarkably similar to those recorded by Melo \& NAKAGAKI (2013) which found 28\% of individuals with empty stomachs. Larger proportions of empty stomachs may be related to samplings during periods of less activity for the prawns. In the present study, samplings were carried out in the morning, and species of the genus Macrobrachium seem to have more intense activity at night (Melo \& NAKAGaKi, 2013).

In general, decapod crustaceans have an opportunistic omnivorous diet and this was confirmed in the present study for M. brasiliense. However, the proportion of animal and plant material is variable and generally, insect and other invertebrates are important components of Macrobrachium species diet. This is the case of M. amazonicum (ODINETZCollart, 1988), M. acanthurus (AlBerToni et al., 2003), M. borelli (Collins \& PAGGI, 1998), M. lar (SETHi et al.,
2013), M. nipponense (Lavajoo et al., 2019) and M. carcinus (Lima et al., 2014). For example, Collins \& PAGGi (1998) found a high frequency of dipteran larvae and oligochaetes for M. borelli. ALBERTONI et al. (2003) also recorded a high proportion of insects for $M$. acanthurus. The diet of $M$. brasiliense evaluated by MELO \& NAKAGAKI (2013) included a high frequency of occurrence of insects remains particularly Chironomidae larvae although algae, Oligochaeta and plant fragments were also recorded.

Although there were similarities between the food items found in the present study and those mentioned above, the quantity and frequency of these items were different. This difference may be related to the wide variation in the diet of freshwater prawn, increasing the spectrum of foods found in the stomachs and to differences in food availability and heterogeneity of habitats among study areas (WILLIAMS, 1981).

The difference in the variety of food items found for $M$. brasiliense between the present study (ten items) and the work of Melo \& NaKaGaKi (2013), in Mato Grosso do Sul (34 itens) confirm that environmental characteristics can be quite significant for determining diet of this species. In the study of Melo \& NAKAGAKI (2013) individuals were collected in stretches of a watercourse with different levels of environmental impact but the diet was evaluated together for the three sites. In this situation, the heterogeneity of habitats sampled and the food items available were higher in relation to our study, resulting in a higher diversity of items found in the diet. Thus, the initial stated hypothesis was confirmed.

The item plant detritus was observed in a proportion always higher than $23 \%$ in both seasons, indicating the importance of this item in the diet of M. brasiliense. Although plant detritus usually presents low nutritional quality, it can be increased by the colonization of decomposing microorganisms (WILLINER et al., 2014). This increase in nutritional value can be direct, since fungi and bacteria 
can be important sources of nutrients, or indirect, due to the decomposing action that can make plant detritus more palatable for shredders, including decapods (Cummins et al., 1973).

Sand was found in a small proportion in relation to the other itens $(\mathrm{OF}<4 \%)$, although this item was widely available to prawns, since the studied stream has a predominantly sandy-muddy bed. There is no consensus opinion regarding the role of sand intake. Some authors consider that the ingestion of sand by decapods is accidental and happens with the ingestion of other items (BRANCO \& MORITZ JÚNIOR, 2001). However, LIMA et al. (2014) states that the sand ingestion can occur as a carbonate source or to help in the food maceration in M. carcinus and in other Macrobrachium species.

In the present study it was observed that females and males have similar diets, so the stated hypothesis was supported. The same pattern was found in studies with $M$. brasiliense (Melo \& NAKAGAKI, 2013) and M. carcinus (Lima et al., 2014). This similarity between diets may be associated with the occupation of the same habitat by males and females during most of the life cycle and / or equivalent metabolic requirements (Melo \& NAKAGAKI, 2013).

For the same species, the existence of diet differences among individuals of different sizes may be due to variation in the ability to capture and process prey of different sizes (OH et al., 1999). Another factor that can result in diet differences due to size are different nutritional requirements between juveniles and adults (BRANCO \& MORITZ JÚNIOR, 2001; SPANJERSBERG et al., 2006). According to Nogueira et al. (2019), M. brasiliense presents different allometric indices for males and females which characterizes sexual dimorphism. Males invest more energy for the development of the second pair of chelipeds, structures possibly used by males in reproductive-related behaviors. Females invest more in the second abdominal pleura, indicating it is an important part of the incubator chamber of females (Mossolin \& Bueno, 2003; Mantelatto \& Barbosa, 2005). Since allocation of energy could be different for those structures the diet differences with size could be related to this differential food investment for growth in males and females.

The absence of a relationship between the size of individuals and the frequency of plant detritus in the diet, indicates that this item is consumed by all size classes of both sexes. However, the linear regressions analyses for total insects and some insect orders showed a positive relationship between size of $M$. brasiliense and frequency (points method) of the items found in the stomachs (Fig. 3 ). Larger males and females tend to consume a higher proportion of insects as a whole than smaller individuals at least at the size range evaluated in the present study. This result is different from that obtained by MELO \& NAKAGAKI (2013) that do not found differences among size classes for total insect consumption. This situation could be related to differences in the composition and proportion of the insect orders consumed by $M$. brasiliense in both studies. The availability of other animal items recorded by MeLo \& NAKAGAKI (2013) (Crustacea, Acari and Oligochaeta) but not recorded in our study could have also been responsible for the different size consumption patterns of $M$. brasiliense.

When items of different animal origin are analyzed separately, it is observed that there was a positive relationship between the size of individuals and the intake of Trichoptera, both for males and females, but this relationship is stronger for males. The same pattern was observed for the intake of Diptera by females. As the number of males with empty stomachs was high, there were not enough males, with the presence of Diptera in the stomach, to perform the analysis, but considering the results obtained in the regression lines for the total insects and Trichoptera, it would be plausible to expect an equal positive relationship.

Diptera was the most abundant group of aquatic insects in the dry and rainy seasons, as already reported in other studies conducted in the region (GUIMARÃES-SOUTO et al., 2011; 2021). Despite this, individuals generally have small dimensions in relation to Trichoptera larvae, which could make the latter a more attractive food resource for $M$. brasiliense. Coleoptera adults and larvae, in turn, although having similar availability to Trichoptera, tend to have higher mobility, which could make predation difficult. Collins \& PAGGI (1998) propose that $M$. borelli would prefer larger and slower prey than smaller and very mobile prey. Thus, the preference of males and females for Trichoptera may be related to a number of factors, including nutritional value and/or ease of predation and food processing of these insects in relation to the others.

The results obtained confirm an omnivorous diet for $M$. brasiliense but a lower variety of food items was recorded in relation to another study of $M$. brasiliense diet that included more preserved areas in Mato Grosso do Sul, central region of Brazil. Only surface water temperature and turbidity varied between dry and rainy seasons suggesting low variation in stream conditions and this variation did not result in diet differences between seasons. Males and females use the same food items in similar proportions indicating they have similar food requirements. Larger individuals of $M$. brasiliense tend to consume a higher proportion of insects as a whole than smaller prawns at least at the size range evaluated in the present study suggesting they can have different requirements and/or capacities to feed different items during their life cycle.

Acknowledgments. We thank A. C. G. Barboza and A. F. Oliveira for their help in the field and in sample processing. We also thank Coordenação de Aperfeiçoamento de Pessoal de Nível Superior - CAPES for Master scholarship granted to B. R. S. C. and Post-graduation Program in Ecology and Conservation of Natural Resources and Universidade Federal de Uberlândia for the logistic support. We also than the Brazilian Council for Scientific Research and Development (CNPq) for supportingthis research through its Long-Term Ecological Research Program (PELD) (CNPq grants 403733/2012-0 and 441225/2016-0). 


\section{REFERENCES}

Albertoni, E. F.; Palma-Silva, C. \& Esteves, F. A. 2003. Natural diet of three species of shrimps in a tropical coastal lagoon. Brazilian Archives of Biology\& Technology: An International Journal 46(3):395-403.

Anger, K. 2013. Neotropical Macrobrachium (Caridea: Palaemonidae): on the biology, origin, and radiation of freshwater-invading shrimp. Journal of Crustacean Biology 33(2):151-183.

BAUER, R.T. 1989. Continuous reproduction and episodic recruitment in nine prawn species inhabiting a tropical seagrass meadow. Journal of Experimental Marine Biology and Ecology 127(2):175-187.

BAuer, R. T. 2004. Remarkable Shrimps: Adaptations and Natural History of the Carideans. Norman, University of Oklahoma Press. $282 \mathrm{p}$.

Benstead, J. P.; March, J. G. \& Pringle, C. M. 2000. Estuarine larval development and upstream post-larval migration of freshwater shrimps in two tropical rivers of Puerto Rico. Biotropica 32(3):545-548.

Bond-Buckup, G.; Buckup, L.; Araujo, P. B.; Zimmer, A. R.; Quadros, A. F.; Sokolowicz, C. C.; Castiglioni, D. S.; Barcelos, D. \& GonçAlves, R. 2009. Crustáceos. In: BoldRINI, I. I. org. Biodiversidade dos Campos do Planalto das Araucárias. Brasília, Ministério do Meio Ambiente, p. 109-129.

Borteiro, C.; Guitiérrez, F.; Tedros, M. \& Kolenc, F. 2009. Food habits of the Broad snouted Caiman (Caiman latirostris: Crocodylia, Alligatoridae) in northwestern Uruguay. Studies on Neotropical Fauna and Environment 44(1):31-36.

Branco, J. O. \& Moritz Júnior, H. C. 2001. Alimentação natural do Camarão sete-barbas, Xiphopenaeus kroyeri (Heller) (Crustacea, Decapoda) na Armação do Itapocoroy, Penha, Santa Catarina. Revista Brasileira de Zoologia 18(1):53-61.

Branco, J. O. \& Verani, J. R. 1997. Dinâmica da alimentação natural de Callinectes danae Smith (Decapoda, Portunidae) na Lagoa da Conceição, Florianópolis, Santa Catarina, Brasil. Revista Brasileira de Zoologia 14(4):1003-1018.

Bueno, A. A. P. \& Bond-Buckup, G. 2004. Natural diet of Aegla platensis Schmitt and A. ligulata Bond-Buckup and Buckup (Crustacea, Decapoda, Aeglidae) from Brazil. Acta Limnologica Brasiliensia 16(2):115-127.

Chace, F. \& HobBs, H. H. 1969. The freshwater and terrestrial decapod crustaceans of the West Indies with special reference to Dominica. United States National Museum Bulletin 292:1-176.

Collins, P. A. \& PAGgi, J. C. 1998. Feeding ecology of Macrobrachium borelli (Nobili) (Decapoda: Palaemonidae) in the flood valley of the river Paraná, Argentina. Hydrobiologia 362:21-30.

Costa, R. C. \& Simões, S. M. 2016. Avaliação dos Camarões Sergestídeos (Decapoda: Sergestidae), Cap. 29. In: Pinheiro, M. A. A. \& Boos, H. org. Livro Vermelho dos Crustáceos do Brasil: Avaliação 20102014. Porto Alegre, Sociedade Brasileira de Carcinologia, p. 390-399.

Cummins, K. W.; Petersen, R. C.; Howard, F. O.; Wuycheck, J. C. \& Holt, V. I. 1973. The utilization of leaf litter by stream detritivores. Ecology 54(2):336-345.

De Grave, S. \& Fransen, C. H. J. M. 2011. Carideorum catalogus: the recent species of the dendrobranchiate, stenopodidean, procarididean and caridean shrimps (Crustacea: Decapoda). Zoologische Mededelingen 85(9):195-589.

Dias, A. M. \& Tejerina-Garro, F. L. 2010. Changes in the structure of fish assemblages in streams along an undisturbed-impacted gradient, upper Paraná River basin, Central Brazil. Neotropical Ichthyology 8(3):587-598.

Dos Santos, A.; Hayd, L. \& Anger, K. 2013. A new species of Macrobrachium Spence Bate, 1868 (Decapoda, Palaemonidae), M. pantanalense, from the Pantanal, Brazil. Zootaxa 3700(4):534-546

Esteves, F. A. 2011. Fundamentos de Limnologia. 3ed. Rio de Janeiro, Interciência. $826 \mathrm{p}$.

García-Dávila, C. R.; Alcantara, F.; Vasquez, E. \& Chujandama, M. 2000. Biologia reprodutiva do camarão Macrobrachium brasiliense (Heller, 1862) (Crustacea: Decapoda: Palaemonidae) em igarapés de terra firme da Amazônia Peruana. Acta Amazonica 30(4):653-664.

García-DÁvila, C. R. \& Magalhães, C. 2003. Revisão taxonômica dos camarões de água doce (Crustacea: Decapoda: Palaemonidae, Sergestidae) da Amazônia Peruana. Acta Amazonica 33(4):663-686.
Guimarães-Souto, R. M.; Facure, K. G.; Pavanin, L. A. \& Jacobucci, G. B. 2011. Influence of environmental factors on benthic macroinvertebrate communities of urban streams in Vereda habitats, Central Brazil. Acta Limnologica Brasiliensia 23(3):293-306.

Guimarães-Souto, R. M.; Facure, K. G. \& Jacobucci, G. B. 2021. Do tropical riparian forests in the Cerrado Biome act as a buffer against the impacts of agriculture and livestock in benthic macroinvertebrate communities? Limnetica (in press).

HAEFNER JÚNIOR, P. A. 1990. Natural diet of Callinectes ornatus (Brachyura: Portunidae) in Bermuda. Journal of Crustacean Biology 10(2):236246.

Haluch, C.; Freitas, M. O.; CorrêA, M. F. M. \& ABILhoA, V. 2009. Variação sazonal e mudanças ontogênicas na dieta de Menticirrhus americanus (Linnaeus, 1758) (Teleostei, Sciaenidae) na baía de Ubatuba-Enseada, Santa Catarina, Brasil. Pan American Journal of Aquatic Sciences 4(3):347-356.

Holthuis, L. B. 1952. A general revision of the Palaemonidae (Crustacea, Decapoda, Natandia) of the Americas. II. The subfamily Palaemonidae. Allan Hancock Foundation Publications, Occasional Papers 12:1-79.

Holthuis, L. B. 1980. Shrimps and prawns of the world: An annotated catalogue of species of interest to fisheries. FAO species catalogue. Fisheries Synopsis 125(1):1-271.

Klink, C. A. \& Machado, R. B. 2005. Conservation of the Brazilian Cerrado. Conservation Biology 19(13):707-713.

Köppen, W. 1948. Climatologia: Con un estudio de los climas de la Tierra. México, DF, Fondo de Cultura Económica. 478p.

Krebs, C. J. 1999. Ecological Methodology. 2ed. Benjamin Cummings, Menlo Park. 620p.

Lavajoo, F.; Biuki, N. A.; Khanipour, A. A.; Mirzajani, A.; Fruitos, J. G. \& AKBARZADEH, A. 2019. Natural diet of Macrobrachium nipponense shrimp from three habitats in Anzali Wetland, Iran. Caspian Journal of Environmental Sciences 17(2):101-111.

Lima, J. F.; Garcia, J. S. \& Silva, T. C. 2014. Natural diet and feeding habits of a freshwater prawn (Macrobrachium carcinus: Crustacea, Decapoda) in the estuary of the Amazon River. Acta Amazonica 44(2):235-244.

MAgAlHÃES, C. 2000. Diversity and abundance of decapod crustaceans in the Rio Negro basin, Pantanal, Mato Grosso do Sul, Brazil. In: WILlinK, P. W.; Chernoff, B.; Alonso, L. E.; Montambault, J. R. \& Lourival, R. eds. A Biological Assessment of the Aquatic Ecosystems of the Pantanal, Mato Grosso do Sul, Brazil. RAP Bulletin of Biological Assessment 18. Washington, Conservation International, p. 5662.

Magalhães, C.; Campos, M. R.; Collins, P. A. \& Mantelatto, F. L. 2016a. Diversity, distribution and conservation of freshwater crabs and shrimps in South America. In: A global overview of the conservation of freshwater decapod crustaceans. Cham, Springer, p. 303-322.

Magalhães, C.; Pilleggi, L. G. \& Mantelatto, F. L. 2016b. Avaliação dos Eurirrinquídeos (Decapoda: Euryrhynchidae). Cap 12. In: PINHEIRO, M. A. A. \& Boos, H. org. Livro Vermelho dos Crustáceos do Brasil: Avaliação 2010-2014. Porto Alegre, Sociedade Brasileira de Carcinologia, p. 157-166.

Mantelatto, F. L. M. \& Barbosa, L. R. 2005. Population structure and relative growth of freshwater prawn Macrobrachium brasiliense (Decapoda, Palaemonidae) from São Paulo State, Brazil. Acta Limnologica Brasiliensia 17(3):245-255.

Mantelatto, F. L.; Pileggi, L. G.; Magalhães, C.; Carvalho, F. L.; Rocha, S. S.; Mossolin, E. C.; Rossi, N. \& Bueno,S. L. S. 2016 a. Avaliação dos Camarões Palemonídeos (Decapoda: Palaemonidae), Cap. 20. In: Pinheiro, M. A. A. \& Boos, H. org. Livro Vermelho dos Crustáceos do Brasil: Avaliação 2010-2014. Porto Alegre, Sociedade Brasileira de Carcinologia, p. 252-267.

Mantelatto, F. L.; Torati, L. S.; Pileggi, L. G.; Mossolin, E. C.; Terossi, M.; Carvalho, F. L.; Rocha, S. S. \& Magalhães, C. 2016 b. Avaliação dos Camarões Atiídeos (Decapoda: Atyidae), Cap. 5. In: Pinheiro, M. A. A. \& Boos, H. org. Livro Vermelho dos Crustáceos do Brasil: Avaliação 2010-2014. Porto Alegre, Sociedade Brasileira de Carcinologia, p. 93-102.

Melo, G. A. S. 2003. Manual de identificação dos Crustacea Decapoda de água doce do Brasil. São Paulo, Loyola. 430p.

Melo, M. S. \& NaKagaKi, J. M. 2013. Evaluation of the feeding habits of Macrobrachium brasiliense (Heller, 1862) in the Curral de Arame stream (Dourados/Mato Grosso do Sul, Brazil). Nauplius 21(1):25-33. 
Menge, B. A.; Berlow, E. L.; Blanchette, C. A.; Navarrete, S. A. \& YAMADA, S. B. 1994. The keystone species concept: variation in interaction strength in a rocky intertidal habitat. Ecological Monographs 64(3):249-286.

Mesa, L. M.; Reynaga, M. C.; Correa, M. Del V. \& Sirombra, M. G. 2013. Effects of anthropogenic impacts on benthic macroinvertebrates assemblages in subtropical mountain streams. Iheringia, Série Zoologia 103(4):342-349.

Mossolin, E. C. \& Bueno, S. L. S. 2003. Relative growth of the second pereiopod in Macrobrachium olfersi (Wiegmann, 1836) (Decapoda, Palaemonidae). Crustaceana 76(3):363-376.

Mugnai, R.; Nessimian, J. L. \& Baptista, D. F. 2010. Manual de identificação de macroinvertebrados aquáticos do Estado do Rio de Janeiro. Rio de Janeiro, Technical Books Editora. 174p.

Nogueira, C. S.; Oliveira, M. S.; Jacobucci, G. B. \& Almeida, A. C. 2019. Relative growth of freshwater prawn Macrobrachium brasiliense (Decapoda, Palaemonidae) and its implications for reproduction. Iheringia, Série Zoologia 109:e2019005.

Odinetz-Collart, O. 1988. Aspectos ecológicos do camaräo Macrobrachium amazonicum (Heller, 1862) no Baixo Tocantins (PA-Brasil). Memoria Sociedad de Ciencias Naturales La Salle 48:341-353.

Odinetz-Collart, O. \& Moreira, L. C. 1993. Potencial pesqueiro de Macrobrachium amazonicum na Amazônia Central (Illha do Careiro): variação da abundância e do comprimento. Amazoniana 12(3-4):399413

OH, C. W.; Hartnoll, R. G. \& NaSh, R. D. M. 1999. Population dynamics of the common shrimp, Crangon crangon (L.), in Port Erin Bay, Isle of Man, Irish Sea. Journal of Marine Science 56(5):718-733.

Oliveira, L. J. F.; Sant'Anna, B. S. \& Hattori, G. Y. 2019. Population biology of the freshwater prawn Macrobrachium brasiliense (Heller, 1862) in the Middle Amazon Region, Brazil. Tropical Zoology 32(1):19-36.

Pereira, M. G. C. \& Chacur, M. M. 2009. Estrutura populacional de Macrobrachium brasiliense (Crustacea, Palaemonidae) do Córrego Escondido, Batayporã, Mato Grosso do Sul, Brasil. Revista Biologia Neotropical 6(1):75-82.
Pileggi, L. G. \& Mantelatto, F. L. 2012. Taxonomic revision of doubtful Brazilian freshwater shrimp species of genus Macrobrachium (Decapoda, Palaemonidae). Iheringia, Série Zoologia 102(4):426-437.

PilegGi, L. G.; Magalhães, C.; Bond-Buckup, G. \& Mantelatto, F. L. 2013. New records and extension of the known distribution of some freshwater shrimps in Brazil. Revista Mexicana de Biodiversidad 84(2):563-574.

Rossi, N.; Magalhães, C.; Mesquita, E. R. \& Mantelatto, F. L. 2020. Uncovering a hidden diversity: a new species of freshwater shrimp Macrobrachium (Decapoda: Caridea: Palaemonidae) from Neotropical region (Brazil) revealed by morphological review and mitochondrial genes analyses. Zootaxa 4732(1):177-195.

Saengrhan, N.; Panijpan, B.; Senapin, S.; Laosinchai, P.; Ruenwongsa, P.; Suksomnit, A. \& Phiwsaiya, K. 2018. Morphology and molecular phylogeny of Macrobrachium suphanense sp. nov. (Decapoda: Palaemonidae) from Thailand. Zootaxa 4482(1):151-163.

Santos, M. A. L.; Castro, P. M. \& Magalhães, C. 2018. Freshwater shrimps (Crustacea, Decapoda, Caridea, Dendrobranchiata) from Roraima, Brazil: species composition, distribution, and new records. Check List 14(1):21-35.

Sethi, N.; Ram, N. \& Venkatesan, V. 2013. Food and feeding habits of Macrobrachium lar (Decapoda, Palaemonidae) from Andaman and Nicobar Islands, India. Indian Journal of Fisheries 60(4):131-135.

Spanjersberg, G.; Roux, A. \& Caille, G. 2006. Composición cualitativa de la dieta del camarón Artemesia longinaris Bate, 1888 (Decapoda, Penaeidae) de Bahía Engaño (Chubut), Argentina. Boletín del Instituto Español de Oceanografía 22(1-4):99-111.

Wear, R. G. \& Haddon, M. 1987. Natural diet of the crab Ovalipes catharus (Crustacea, Portunidae) around central and northern New Zealand. Marine Ecology Progress Series 35:39-49.

WiLLIAMS, M. J. 1981. Methods for analysis of natural diet in portunid crabs (Crustacea: Decapoda: Portunidae). Journal of Experimental Marine Biology and Ecology 52(1):103-113.

Williner, V.; Carvalho, D. A. \& Collins, P. A. 2014. Feeding spectra and activity of the freshwater crab Trichodactylus kensleyi (Decapoda: Brachyura: Trichodactylidae) at La Plata basin. Zoological Studies 53:71.

ZAR J. H. 2010. Biostatistical Analysis. 5ed. Upper Saddle River, PrenticeHall. 944p. 